AP: Ontine Journat in Public Archaeology special Volume 3 - 2018 p. 221-248

\title{
Exploring your Inner Hades: DNA as Mortuary Archaeology
}

Tom BOOTH

Natural History Museum, London, UK

Received: 07/09/2017 - Accepted: 26/06/2018

\section{Abstract}

Two revolutions in using human genetics to investigate the past are beginning to have a profound effect on how the public regard heritage and their connection to it. Direct-to-consumer genetic ancestry tests (GATs) are becoming a popular way for the public to explore their familial history and ancestry. Major advances in ancient DNA methods mean that the field is beginning to live up to its early promise. Both of these analyses can be considered forms of public mortuary archaeology in how they are perceived to provide an individual an interface with their recent and more ancient ancestors, their own personal Hades, referring to the Ancient Greek home of the dead. GATs are useful for resolving genealogy and determining the origins of an individual's recent ancestors, but have been criticized for reifying differences between populations, failing to give clear guidance on how they should be interpreted, and making exaggerated links to historic groups of people that are at the heart of genetically determinist nationalistic origin myths. Recent palaeogenomic studies of prehistoric Europeans have found evidence for population discontinuity that will have repercussions for the public's perception of archaeological mortuary sites and the communities who built them. Public archaeologists are going to have to engage increasingly with these types of data to combat the misappropriation of genetic results in defining rights and affinities to archaeological heritage.

\section{Keywords}

ancient DNA, Genetic Ancestry Tests, nationalism, public archaeology, mortuary archaeology 


\section{Introduction}

Direct-to-consumer genetic ancestry tests (GATs) have become a popular way for the public to directly explore their familial histories, as well as more abstract aspects of their ancestry, identity and heritage (Royal et al. 2010). At the same time, major advances in the sampling, extraction and analysis of ancient DNA have facilitated powerful palaeogenetic studies of ancient human remains highlighting, amongst many other things, population discontinuity in prehistoric Europe (Allentoft et al. 2015; Fu et al. 2016; Haak et al. 2015; Olalde et al. 2018). Both GATs and palaeogenomics may be regarded as forms of contemporary mortuary archaeology, and digital public mortuary archaeology (DPMA) in particular, in that they are represented through virtual digital media and data that encourage the public to explore and define relationships between themselves and their long-deceased ancestors (Williams and Atkin 2015). They therefore form an interface between the public and past communities (Moshenska 2017). The way in which both disciplines enter and influence societal and political discourse, whilst often being regarded as recreational or academic, as well as how they provoke tensions between authority and multivocality in narratives of populations and individuals, means that they are subject to some of the same issues that are often at the forefront of discussions in public archaeology more generally (Richardson and Almansa-Sánchez 2015).

Human palaeogenomics is mortuary archaeology in a straightforward way, as it deals directly with ancient human remains retrieved from archaeological investigations of mortuary sites. Both GATs and palaeogenomics produce rich datasets representing the individual, but also a population of that individual's ancestors (Royal et al. 2010). The data are stored in online databases such as the NCBI GenBank, producing large datasets composed of biological information from an individual and their ancestors. This adds to the growing list of types of non-corporeal or non-material forms of public mortuary archaeology (Williams and Atkin 2015). Ancient geneticists are now also 'death-workers' who have a key role in constructing narratives of dead individuals and populations, sometimes with little involvement from archaeologists (Giles and Williams 2016: 12). Unlike other archaeological scientists, most palaeogeneticists have little formal training in human osteology 
or funerary archaeology. Some of the conclusions of these palaeogenetic studies have taken archaeologists by surprise, and there are still lingering tensions between the two disciplines, often fueled by misunderstandings regarding their respective research interests, methodologies and interpretations (Furholt 2018; Heyd 2017).

The ability to treat DNA data from an ancient individual as representative of a population has allowed geneticists to make bold assertions about prehistoric population movements based on what might be regarded as relatively small sample sizes (Allentoft et al. 2015; Fu et al. 2016; Haak et al. 2015; Olalde et al. 2018). Caution must always be exercised in assessing archaeological representation biases, but genetic information from both ancient and modern individuals facilitates investigation of early and more recent populations whose remains may not have survived into the archaeological record. This concept is usually taken for granted in palaeogenetics papers, but this subtlety is often lost on archaeological specialists and the public. Narratives derived from palaeogenetic studies often provoke sensational headlines in national media, and this is often how most archaeological specialists initially encounter these results. The hard science and academic papers are often difficult for archaeologists to scrutinize, and sometimes geneticists cannot fully explore the range of arguments and approaches to particular archaeological questions, which can often lead to archaeologists feeling divorced from the findings of palaeogenomics, and perhaps may lead them to consider the subject of palaeogenomics outside their area of expertise. The potential for an absence of archaeological expertise in both palaeogenomics and GATs may set them apart from other forms of public archaeology (Moshenska 2017).

This article will explore the ways in which GATs and palaeogenomics represent forms of contemporary public mortuary archaeology and the way that they affect relationships between the public and their recent ancestors, as well as their relationships with ancient peoples (including the artefacts, ancient monuments and landscapes they leave in the landscape). It will explore how these types of studies may affect perceptions of more traditional forms of mortuary archaeology, focusing mainly on Europe, and on Britain in particular. It will provide some ideas about what GATS can and 
cannot be used to say about relationships between modern and ancient populations, in order to provide some guidance on how to combat the misappropriation of these data in public discourse.

\section{GATs}

There are an increasing number of companies that offer personalized DNA sequencing services for a bewildering variety of purposes, although GATs are by far the most popular and numerous (Phillips 2016). The tests do not involve sequencing of an individual's entire genome, but specific genetic variants that have been identified as helpful for discriminating between modern-day national populations and assessing relatedness between individuals (Jobling et al. 2016; Royal et al. 2010). GATs have fairly discrete genealogy and ancestry functions that have different implications to inferring relationships between the living and the dead.

The genealogical aspect of GATs involves the search for DNA sequences that consenting individuals in the company's databases may have in common (Royal et al. 2010). The abundance and length of shared DNA sequences between individuals can be used to estimate the degrees of relatedness, and identify extended family members. This information can be essential to resolving genealogical quandaries, and GATs are demonstrably useful for identifying longlost relatives or resolving family trees (Tutton 2004). However, they also have an inherent disruptive potential, as there is always a possibility that the results will clash with the genealogical record, or even a person's own accepted family history (for example, in identifying an instance of misattributed paternity). This highlights a recurring theme of GATs, as well as palaeogenetic analyses, that is directly relevant to issues raised in public archaeology. Namely, that unexpected or unintuitive results have the potential to alter an individual's perceived relationship with distinct ancestors, ancient peoples and related aspects of identity and heritage (Lee 2013; Scully et al. 2016).

GATs usually construct representations of an individual's ancestry through two methods: sequencing of hundreds of thousands of genetic variants (usually single nucleotide polymorphisms (SNPs) - positions in the human genome that are commonly variable 
between individuals) distributed across an individual's whole genome and analysis of uniparental markers (DNA sequences inherited exclusively through the maternal (Mitochondrial DNA) or paternal (Y-chromosome) lineage). Data obtained across an individual's whole genome is used to produce ancestry composition tests. These tests use algorithms to calculate the combination of SNPs commonly found in modern national source populations best explains SNP variation in an individual's genome (Royal et al. 2010). The result is usually expressed as percentages relating to the proportion of SNPs an individual has in common with particular populations. Ancestry composition tests are at the forefront of GAT marketing, and have been linked explicitly with relationships to historic groups of people intrinsic to notions of national, regional and individual identity (Nordgren and Juengst 2009; Figures 1 and 2 ). These marketing strategies commodify ancestry by placing it at the heart of an individual's sense of identity and heritage (Bliss 2013; Scodari 2017).

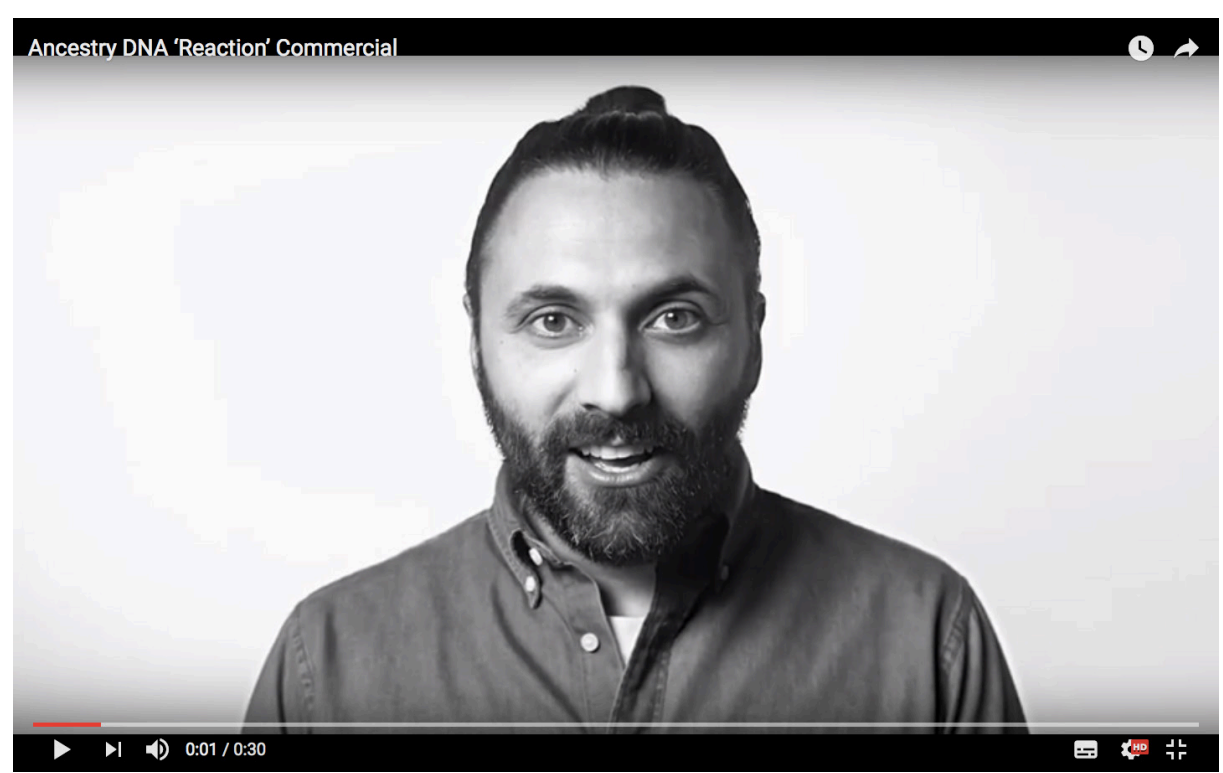

Figure 1: https://www.youtube.com/watch?v=hpJ6TFmrs10 Ancestry DNA 'Reaction' Commercial depicting a man's reaction to being told that he 'is a Viking.' This advertisement highlights that the possibility that GATs can make connections between individuals and particular historical populations; these are often at the forefront of GAT company marketing strategies. 


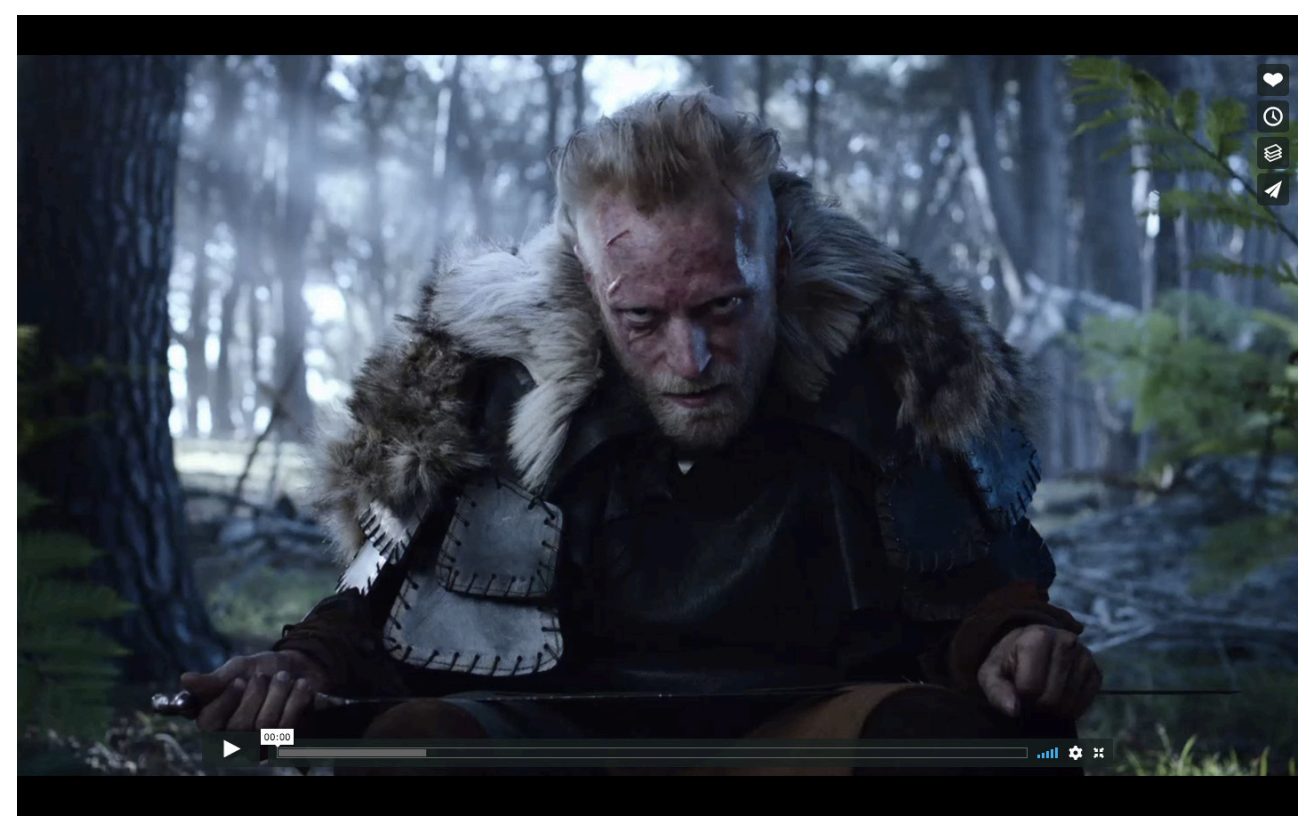

Figure 2: https://vimeo.com/135006750

Ancestry 'Come Find Me' Commercial depicting a Viking inviting viewers to discover who their ancestors were and 'where their story began'. This advertisement also prioritizes the suggestion that GATs can link modern individuals to specific historical populations that feed into ideas around nationhood and identity.

There is no doubt that population genetics provides tangible and effective methods of distinguishing between different modern and ancient populations. Of course, genetic variants associated with particular modern populations do relate to the population history of particular regions, and comparison of data from each can be a powerful way of investigating past demographic processes, although the nature and antiquity of the processes they capture is sometimes unclear ((Kershaw and Røyrvik 2016; Leslie et al. 2015). However, the presentation of GAT ancestry composition tests, emphasizing differences between populations supposedly reaching back into deep time and linking differences to historical populations and aspects of contemporary identity has been criticized on several fronts (Jobling et al. 2016; Morning 2014; Nash 2004; 2005; 2012a; 2012b; 2013; 2015; 2016; 2017; Nordgren and Juengst 2009; Phelan et al. 2014). The SNPs that 
are studied for these ancestry composition tests represent a tiny proportion of an individual's genome, yet an individual's ancestry composition is normally presented in percentage terms, potentially giving a misleading impression of the significance of differences between populations (Jobling et al. 2016; Phelan et al. 2014; Royal et al. 2010). DNA sequences are so data-rich that even a small proportion of a genome can be used to discriminate between modern populations on a probabilistic basis. However, there is some evidence that public awareness of what GATs claim to do reifies concepts of inherent human racial differences that has been characterized as a new form of racialism (Morning 2014; Phelan et al. 2014). This is in spite of the fact that studies on both ancient and modern populations have clearly undermined traditional racial categories; therefore, this disconnect between results and interpretation may represent public misunderstandings this technology (Fujimura et al. 2007; Reich 2018). The inference by GATs that modern genetic differences have persisted through deep time, and particularly the evocation of ancient populations that are at the heart of modern national foundation myths, has been argued to encourage ethnic nationalism, building genetically essentialist notions of modern peoples that can facilitate nativist political narratives (Nash 2015; 2017; Nordgren and Juengst 2009). This situation is exacerbated by use of categories that are a mixture of genuine ethnic groups, nationalities (some of which have only existed in the recent past) and vague geographic regions of variable size (e.g. Ashkenazi Jewish, French, German, Italian). These categories are defined by the ease at which populations can be distinguished using the methodologies used by GAT companies, but the way they are labelled potentially creates a false equivalency between terms and strips them of their sociocultural and historical components. The specificity of some of these categories has been questioned on the basis that current methods used by GAT companies can only allocate ancestry at continental resolutions with high confidence (Jobling et al. 2016). The results of GATs are often perceived by the public, as well as marketed by the companies, as a way of using their ancestors to link themselves to historic populations and legitimize aspects of their identity. In doing so, GATs promote a questionable ideal that deep ancestry and connections to ancient groups are imperative to a person's individual national identity and belonging, ideas that have deep roots in ethnic nationalism. 
GATs differ subtly from this popular perception, mostly because of the way they transform raw genetic data into comprehensible ancestry compositions, but also because of limitations on what modern genomes can be used to say about ancient ancestors (Jobling et al. 2016; Royal et al. 2010). The source populations used in GATs are usually composed of individuals whose grandparents were all documented to have lived in the same region or modern nation and often those who self-identify as 'white' in European countries (Durand et al. 2014). This strategy is intended to narrow down samples to individuals who are likely to have the longest ancestral legacy in a particular region, therefore taken to be broadly representative of the general population of that area over a maximal time period. GAT companies suggest that this allows them to acquire a genetic signal for particular regions which existed before more recent periods of significant migration, and which would be assumed to have been static for the last few hundred years (Durand et al. 2014). This may be true in a broad sense, but without hundreds of ancient genomes dating back over the last few hundred years, this assumption is currently difficult to test. Most individuals used in these source populations will inevitably have ancestry from other places, but the statistical techniques used by GAT companies zero in on average differences between populations. The size of the area can vary and is at least partly dependent on the degree of genetic differentiation between populations living in particular regions. Crucially, the data from these source populations are curated to some extent to produce statistically coherent groups, and are likely to represent relatively conservative representations of genetic variation in these groups.

The algorithms used by GATs apply principals of population genetics to an individual's genome and are based on robust but probabilistic models that were primarily developed for comparing populations rather than individuals (Jobling et al. 2016; Royal et al. 2010). Each company has their own source populations and algorithms, and therefore each one produces slightly different results for the same individual. In addition, the conservative construction of population groups, small or unrepresentative source populations and historic relationships between geographically close groups can mean that certain sequences are misattributed and produce results that are known (through detailed family records) to be anomalous. Therefore, GATs represent an individual's historic 
ancestors defined through a prism of modern population variation and culturally derived categorizations (Jobling et al. 2016).

It is currently difficult to determine the time-depth that GATs represent with respect to past populations, but is probably no more than a few hundred years (Jobling et al. 2016; Royal et al. 2010). This is a pertinent factor for consumers who believe GATs will reveal something about their deep ancestry, particularly how it fits with the popular conception of the origins of regional and national populations. However, despite some GAT companies trading on this connection, they tend to be vague about the antiquity of the ancestors their tests represent (Durand et al. 2014). Contrary to the marketing by some companies, GAT ancestry compositions cannot provide robust insight into a modern individual's connection with distant early medieval populations that are often at the heart of European nationalist myths. Very few GATs produce results suggesting an individual has an exclusive genetic stake in a single ancestral category, even over the potentially short time frames they cover (Jobling et al. 2016; Panofsky and Donovan 2017; Scully et al. 2016). The exponential increase in ancestors every generation means that as you go further back in time, each single individual ancestor is likely to be represented to a diminishing degree. The way in which DNA is inherited in chunks means that sequences from a particular genealogical ancestor can be entirely replaced through time, leaving an apparently paradoxical situation in which an individual has genealogical ancestors that are not represented in their DNA (Royal et al. 2010). As an individual's genealogical ancestors increase exponentially with each generation, the population of a particular region is usually decreasing, and so it quickly becomes inevitable that this population of ancestors will include people from diverse places. The European genetic isopoint (the point at which everyone that lived in Europe and passed on descendants is an ancestor of all present-day white Europeans) is in the ninth century $A D$, around the time of the Viking colonization of Britain and well after the arrival of the Anglo-Saxons (Ralph and Coop 2013). A similar isopoint for the entire world population is estimated to be only a few thousand years ago (Rohde et al. 2004). Therefore, every present-day person with recent European ancestry from any country will inevitably have genealogical ancestors from the first millennium AD who lived in every part of Europe and could 
be equally afforded early medieval cultural/ethnic terms as much as any other, such as 'Anglo-Saxon', 'Viking' or even 'Celt'. The population of genealogical ancestors from the first millennium $A D$ and almost certainly a proportion from the second millennium $A D$ would have lived outside of Europe. Of course, certain early medieval groups had disproportionate genetic influences in particular regions which may have persisted to some extent through time, meaning that it is likely that genetic signatures of modern populations will reflect the influence of historic groups to some extent (Leslie et al. 2015), but for the reasons described above it is impossible to make confident statements regarding the links with a modern individual. GATs can only pertain to a selection of an individual's ancestors who in most cases probably existed relatively recently.

GAT companies largely leave it up to their customers to interpret the meaning of their results when it comes to the depth of ancestry (Jobling et al. 2016). In many cases this allows their customers to mould their results to fit their preconceived sense of their own family history, ancestry and identity. In this situation, the customer always gets what they want, as their family legends or ideologies regarding their relationship with past peoples are seen to be given an objective scientific grounding (Lee 2013; Scully et al. 2013; 2016). The way GAT companies often leave their results open to interpretation has led them being labelled as 'genetic astrology' (Balding et al. 2013). Even if customers venture online to attempt to understand their results, the variety of possible websites, blogs and social media accounts available could be used to support most interpretations. The predictable interest that ethnic nationalist groups have in DNA means that they are often overrepresented amongst these sites. A lack of expertise in GATs amongst archaeologists may make it difficult for them to challenge narratives of individuals and population histories that develop from interpretations of GATs, which adds to the potentially problematic ways in which archaeological expertise may be undermined in digital contexts (Richardson 2014). The reflexive way in which a large number of people, particularly those with predominantly recent European ancestry, reflects the perception of these tests as 'low stakes' and recreational, with only a small impact on their lives beyond their perception of self. However, as has been argued in the public archaeology literature, there is a broader argument over 
how far knowledge and results of tests spill over into ideas around society, heritage and identity (Nash 2015; 2017; Richardson and Booth 2017). The stakes are tangibly higher for people from other parts of the world. For instance, in North America ancestry results pertaining to Native American ancestry can be seen to affect political legitimacy (TallBear 2013).

White nationalists perceive themselves to have a more explicit high stakes investment in the results of GATs. A study of posts on the Stormfront white supremacist online messageboard suggests that many see these GATs as a way of legitimizing their 'whiteness', which in their minds is defined by a high proportion of European ancestry (Panofsky and Donovan 2017). These ideas of 'whiteness' and genetic continuity with ancient populations are often linked with determinist notions of behaviour and culture. Inevitably, GATs often subvert expectations, revealing ancestors from continents other than Europe. However, the most common response to unexpected results is rejection, either through criticism of the methodologies used by the testing companies, anti-Semitic conspiracy theories or shifting goal-posts (Panofsky and Donovan 2017: 27). This highlights that whilst GATs have the potential to be a disruptive form of public mortuary archaeology when it comes to biological essentialist notions of peoples, this is often ignored or rationalized reflexively if it contradicts a person's pre-established sense of identity (Panofsky and Donovan 2017; Scully et al. 2013; 2016). This selective reaction to GATs further demonstrates that, in spite of their disruptive potential, they are more often appropriated to support an individual's preconceived ideas. This is in common with other forms of public archaeology that are selectively coopted and interpreted to fit particular ideologies, particularly those related to nationalism (Sommer 2017). This parallels the tensions surrounding intellectual authority and multi-vocality in Western Europe. Multi-vocal approaches, particularly in North America, can engage wide audiences, give indigenous groups agency and stake in archaeological interpretations of their heritage and produce broader discussions that are of benefit to discussions around archaeology and heritage (for example: Hodder 2008; McClelland and Cerezo-Román 2016), but this should not extend to allowing scientific analyses to be misrepresented, particularly for egregious purposes, and in these cases this requires some 
acknowledgement of expertise (Grima 2017; Merriman 2004). For instance, in Western Europe multi-vocal approaches may open archaeological interpretation to fringe ideas and ideologies that misrepresent primary evidence (Merriman 2004; Richardson 2014; Grima 2017). Similar to certain fringe narratives of archaeological sites constructed by non-experts, the results of GAT tests have the potential to be misunderstood or misrepresented to prop up particular extreme ideologies (Grima 2017; Sommer 2017).

Some companies also offer to characterize an individual's uniparental markers in an attempt to explore deeper aspects of an individual's maternal and paternal ancestry (Jobling et al. 2016). Accumulated random mutation in these parts of the genome can be classified into trees of related categories, named 'haplogroups'. As different haplogroups emerge at different times and in different locations, they occur at variable frequencies amongst world populations. Uniparental genetic markers are often used on a population level to discuss maternal/paternal genetic population affinities and movements.

In relating to a specific lineage of ancestors, an individual's uniparental markers potentially provide a clearer line of descent that reaches back into the deep past. For instance, a study of modern DNA from the north of England found an association between rare Norse-derived surnames and Y-chromosome haplogroups associated with Scandinavia, which is most likely related to early medieval diaspora of Scandinavian groups around the North Sea and Irish Sea in the ninth and early tenth centuries AD (King and Jobling 2009). However, in representing a small and very specific proportion of an individual's ancestors, these markers are often not particularly meaningful in a broad biological sense, and can contrast with results from an individual's whole genome (Emery et al. 2015; Jobling et al. 2016; Lee 2013; Royal et al. 2010). Many world populations include a diversity of uniparental haplogroups, and distinguishing between them is usually based on ratios at a population level. Therefore, extrapolating the origins of a single individual's uniparental lineage on the preponderance of a particular haplogroup in other national populations can be inaccurate. In addition, defining modern identity or heritage through either of these markers is inherently gendered in arbitrarily a small group of direct all-male or all-female ancestors (Nash 2012). In sum, the analysis of genome-wide SNPs and uniparental 
markers in modern populations has undeniable applications to the study of past population history, but for a variety of reasons they are limited in connecting a modern individual with ancient peoples. GAT companies have no stake in communicating these limitations to the public, leaving their ancestry tests open to interpretation and potentially abuse by individuals and groups promoting nationalist ideologies.

\section{Ancient DNA and traditional mortuary archaeology}

Major breakthroughs in sequencing technology, sampling and laboratory methods have revolutionized the extraction and analysis of ancient DNA. These methods have been applied to a range of prehistoric human remains, leading to the discovery of new groups of humans with whom our species interbred, and have gone some way to resolving the issue of the prehistoric population history of Europe (Allentoft et al. 2015; Fu et al. 2016; Haak et al. 2015; Olalde et al. 2017; Prüfer et al. 2014). Genetic evidence of inbreeding events between humans and extinct hominins such as Denisovans have also led the media and the public to reflect on the meanings of their relationships to extinct humans. An extreme example, again originating from the Stormfront message board study, is the suggestion that Neanderthal genetic variants contribute to the reduced skin pigmentation and inherent superiority of white Europeans, particularly compared to most human populations in sub-Saharan Africa, who, have no Neanderthal ancestry (Panofsky and Donovan 2017: 2). Yet research has shown that prehistoric movements of Eurasian populations into Africa mean that people inhabiting parts of eastern Africa today do have some Neanderthal ancestry (Llorente et al. 2015). In addition, Neanderthal ancestry is currently highest in populations living in East Asia (Wall et al. 2013). Genetic variants that modern populations have inherited from Neanderthals include ones linked to pigmentation, however these variants have been shown to contribute to both lighter and darker pigmentation (Dannemann and Kelso 2017). The persistent spurious association between Neanderthal ancestry and 'whiteness' provides an example of how interpretations of palaeogenomic data, filtered uncritically through an individual's pre-existing belief systems, can result in the misappropriation or misrepresentation 
of scientific findings. This echoes similar misrepresentations of archaeological evidence in the service of particular ideologies that public archaeology, is in part intended to combat (Scully et al. 2013; Richardson and Almansa-Sánchez 2015; Jobling et al. 2016; Scully et al. 2016; Grima 2017; Moshenska 2017; Sommer 2017).

These examples show how multiple narratives of palaeogenetic evidence do develop, although the overwhelming authority of qualified geneticists ensures that these ideas are usually condemned to the fringes of public discourse. However, these spurious interpretations of the genetic data may enter into public discussions of archaeology and heritage, particularly on the internet, and may be particularly difficult to challenge in cases where archaeologists do not have some expertise in genetics or palaeogenomics. Ethnic nationalist ideologies are often considered at the fringes of society in Western Europe, although they are often implicit and prevalent in public discussions of migration, identity and nationality, particularly in certain parts of the media and online (Fligstein et al. 2012). These issues have come to the fore in Britain more obviously due to conversations around nationalism and identity triggered by the Brexit and Scottish independence referendums (Richardson and Booth 2017; Zmigrod et al. 2017). Ethnic nationalism is entrenched in more eastern parts of Europe such as Hungary and the Ukraine (Bugajski 2016). These ideologies commonly misuse public archaeologies, including genetics to justify themselves and have the potential to be reciprocally influential in public archaeology and public mortuary archaeology specifically, due to the way national heritage is often thought of by the public, and sometimes promoted by archaeologists themselves, as the product of an unbroken biological connection to 'our ancestors' (Sommer 2017).

There have been no direct investigations into how GATs or palaeogenomic studies are affecting the public's relationship with archaeological sites to date. However, the ability of GATs to track deceased ancestors who could not otherwise be located means that there is now potential to broaden the nature and variety of archaeological sites with mortuary dimensions to which people may conceive of themselves as 'belonging to' (including, for example, caves, megalithic tombs, barrows and cairns, as well as churchyards, burial grounds and cemeteries of the historic period). In producing 
connections, or ancestry compositions, which agree with people's preconceived notions of their own ancestry, as well as an 'our ancestors' view of heritage, GATs may also strengthen a person's connection with mortuary sites with which they already had an existing relationship (Smith 2001). On the other hand, GAT results that are contrary to a person's expectations have the potential to disrupt a person's connection to specific archaeological sites (see the discussion of Stonehenge below), although the tendency for individuals to reject contrary results means that any disruptive potential may be buffered to some degree (Panofsky and Donovan 2017; Scully et al. 2013; 2016).

The public's interest in questions of their relatedness to local ancient populations has encouraged studies where DNA from ancient peoples is compared to nearby modern individuals or populations to see how they are related. The most famous example of this approach is the analysis of DNA from the ten thousandyear-old Cheddar Man skeleton from Gough's Cave, Somerset and the inhabitants of the nearby Cheddar village (Sykes 2006). This study claimed to have successfully extracted mitochondrial DNA from Cheddar Man that could be classified as belonging to the ' $U$ ' haplogroup. The study famously also found that mitochondrial DNA from a local schoolteacher belonged to the same haplogroup. The media particularly took this result as indicating that the schoolteacher was the direct descendant of Cheddar Man and that the people of Cheddar had a biological stake in the area which reached back thousands of years (Nuthall 1997). This interpretation misrepresents what mitochondrial DNA can be used to say. Whilst it is faintly possible that the schoolteacher is a maternal direct descendent of Cheddar Man, it is much more likely that they share a common maternal ancestor who existed tens of thousands of years ago. The $U$ haplogroup itself occurs relatively frequently in most modern European populations (Sahakyan et al. 2017). If Cheddar Man has any modern descendants he would be the ancestor of almost every human alive today (Rohde et al. 2004). The Cheddar Man research and subsequent studies into modern British mitochondrial DNA suggesting British population continuity over the last 17,000 years ago have had a lasting legacy on public discourse, and have been misappropriated to promote nativist political ideals (Jobling et al. 2016; Oppenheimer 2006; Figure 3). 
Analysis of palaeogenomes from hundreds of prehistoric Europeans has found evidence of several significant migrations of people from outside the Continent, meaning that modern European populations are mostly genetically discontinuous with the earliest prehistoric inhabitants (Allentoft et al. 2015; Fu et al. 2016; Haak et al. 2015; Olalde et al. 2017). These results could have implications for the public's relationship with mortuary monuments belonging to certain archaeological phases, or at least nudge people towards a more positive and grounded understanding of national heritage where ancestry is less prominent (Smith 2001). For example, a recent palaeogenomic study of the Beaker cultural phenomenon in prehistoric Europe suggests that migrations into Britain associated with the introduction of the Beaker culture (c. $2500 \mathrm{BC}$ ) resulted in an almost complete replacement of the local Neolithic population over a few hundred years (Olalde et al. 2017). This means that modern British populations are largely not directly descended from the builders of Stonehenge: situated in one Britain's largest Late Neolithic ceremonial and mortuary landscapes, and one of its most famous heritage sites. This kind of finding disrupts any biological essentialist or genealogical notions of British heritage that are often implicit in public discourse. However, ethnic nationalist groups by their nature tend to maintain a key interest in new results from both modern and ancient DNA, and often change, reframe or reboot their beliefs accordingly, ignoring any resultant cognitive dissonance, which is why the idea of heritage and nationhood as defined exclusively by DNA ancestry needs to be robustly challenged. The results from the Beaker study may also have important implications for specific stakeholders, such as denominations of neo-druids, for whom the religious significance of Stonehenge is dependent on the site including burials of ancient ancestors (Wallis and Blain 2011).

\section{Discussion}

There is a moral case for public archeologists challenging biologically determinist ideas of nationhood and heritage, however it is useful to be able to demonstrate that these ideologies fail on evidential grounds (Sommer 2017). Even if European prehistory was defined by population continuity, the non-specificity of a modern 


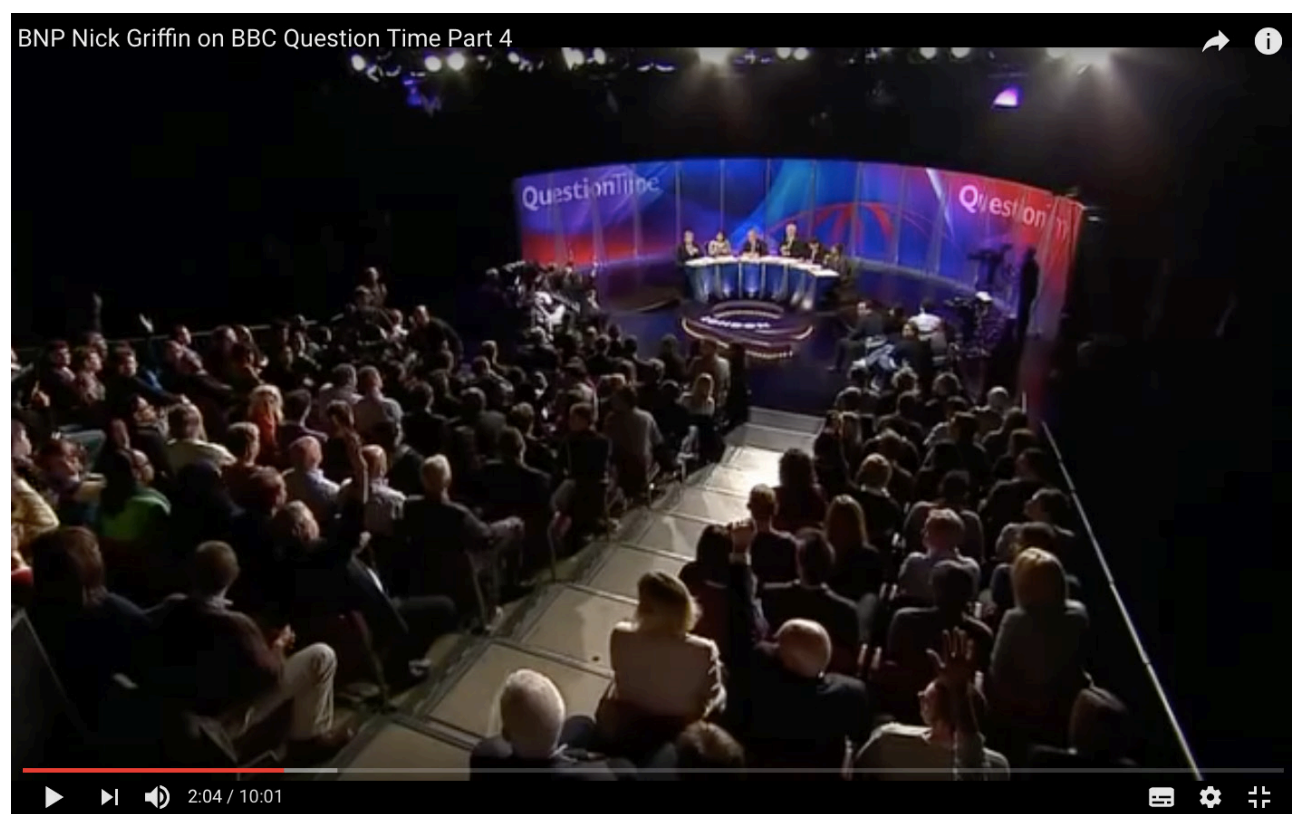

Figure 3: https://www.youtube.com/watch?v=bQE0QPFoLfs

A 20-minute clip of BBC Question Time from 22 October 2009, featuring the then-leader of the British Nationalist Party, Nick Griffin. At 09:07, Nick Griffin refers to the idea of a British 'indigenous' population that has persisted for the last 17,000 years, a claim that originates in previous studies of modern DNA (Oppenheimer 2006) that have now been refuted (Olalde et al. 2018).

individual's deep ancestry means that in most cases their individual genetic stake in archaeological mortuary sites is not particularly meaningful (Ralph and Coop 2013). Individuals recovered from any European cemetery dating to before the ninth century AD will not be the specific ancestors of any local or even national community. The nature of ancestry means that modern nationally or regionally specific ancestry will only begin to emerge in archaeological individuals from the very recent past. As discussed above, GATs mostly reveal that even modern individuals rarely have exclusive recent ancestry in specific nations or geographical regions (Jobling et al. 2016; Panofsky and Donovan 2017). Informed interpretations of GATs, as well as academic studies of modern and ancient genomes, support arguments that no individual's link to a nation or national heritage can be strictly biological, but is a cultural decision that can be based in part on ancestry, which inevitably incorporates 
many other cultural, social and historical factors (Clegg et al. 2013; Jobling et al. 2016).

The disruptive potential of these technologies has been demonstrated most recently and most acutely by mainstream and social media reaction to palaeogenetic analyses, which suggest that Cheddar Man (and, indeed most Mesolithic Europeans) probably had dark skin (Brace et al. 2018), a subject that will be covered in more detail by the author in future publications. However, a lack of public awareness of palaeogenetics, the vagaries of deep ancestry and the limitations of GATs mean that these technologies are often reinforcing pre-existing beliefs.

There is a distinction to be made between accidental misunderstandings of GAT results and palaeogenomics where a lack of expert guidance and the marketing strategies of the GAT companies allows the public to fall back on established historical or familial myths, and interpretations of GATs and palaeogenomics that are driven by ideologies which involve the willful distortion of genetic and archaeological evidence. The problem that public archaeologists face is that the latter often fuels the former, particularly in digital environments, meaning that simplistic biologically essentialist understandings of nationhood and heritage may become more deeply fixed and justified by objective scientific truth in the public imagination (Nash 2012; Richardson and Booth 2017). Therefore the misappropriation and reframing of GAT and palaegenetic studies within nationalist narratives could begin to impact on discourse in archaeological forums and social media where public archaeologists' expertise in genetics may be limited. These issues and tensions mirror those identified in public archaeology and highlight the need for public archaeologists to engage with these new techniques and integrate them into their discourse and strategies, or at least identify trustworthy external authorities that can be used to counter-act distorted narratives, whether that be particular academics or academic papers themselves, blogs or websites. Challenging and subverting national origin myths and their underlying ideologies that misappropriate primary evidence is a core part of public archaeology, therefore both GATS and palaeogenomics are potentially important tools for public archaeologists if they can develop some familiarity with these techniques. 


\section{Conclusion}

Hopefully this article has laid out some simple notions of what palaeogenomics and GATs can and cannot be used to say about relationships between modern and ancient populations and individuals, which can be used to aid archaeologists engaging in public debate on these matters. Public scientists with specialisms in genetics such as Dr Adam Rutherford and Dr Jennifer Raff are already successfully tackling misrepresentations of GATs and palaeogenomics on social and traditional media, but it is difficult to say how far this work has yet influenced public archaeologists, and discussions of identity and heritage. The rising public profile of GATs and palaeogenomic studies mean that they will inevitably begin to influence public perception of history, society and heritage. Reasoned discussion of human ancestry and recent palaeogenomics findings show how this position is no longer tenable in an era of growing political populism and nationalist sentiment. This is a significant opportunity for public archaeologists to the ideological and intellectual arguments contained in narratives of history and heritage that misrepresent or misappropriate primary evidence.

\section{References}

Allentoft, M.E., Sikora, M., Sjögren, K.-G., Rasmussen, S., Rasmussen, M., Stenderup, J., Damgaard, P.B., Schroeder, H., Ahlström, T., Vinner, L., Malaspinas, A.-S., Margaryan, A., Higham, T., Chivall, D., Lynnerup, N., Harvig, L., Baron, J., Casa, P.D., Dabrowski, P., Duffy, P.R., Ebel, A.V., Epimakhov, A., Frei, K., Furmanek, M., Gralak, T., Gromov, A., Gronkiewicz, S., Grupe, G., Hajdu, T., Jarysz, R., Khartanovich, V., Khokhlov, A., Kiss, V., Kolář, J., Kriiska, A., Lasak, I., Longhi, C., Mcglynn, G., Merkevicius, A., Merkyte, I., Metspalu, M., Mkrtchyan, R., Moiseyev, V., Paja, L., Pálfi, G., Pokutta, D., Pospieszny, Ł., Price, T.D., Saag, L., Sablin, M., Shishlina, N., Smrčka, V., Soenov, V.I., Szeverényi, V., Tóth, G., Trifanova, S.V., Varul, L., Vicze, M., Yepiskoposyan, L., Zhitenev, V., Orlando, L., Sicheritz-Pontén, T., 
Brunak, S., Nielsen, R., Kristiansen, K. and Willerslev, E. 2015. Population genomics of Bronze Age Eurasia. Nature 522(7555), 167-172. DOI: $10.1038 /$ nature 14507

Bliss, C., 2013. The marketization of identity politics. Sociology 47(5), 1011-1025. DOI: 10.1177/0038038513495604

Brace, S., Diekmann, Y., Booth, T.J., Faltyskova, Z., Rohland, N., Mallick, S., Ferry, M., Michel, M., Oppenheimer, J., Broomandkhoshbacht, N., Stewardson, K., Walsh, S., Kayser, M., Schulting, R., Craig, O.E., Sheridan, A., Parker Pearson, M., Stringer, C., Reich, D., Thomas, M.G. and Barnes, I. 2018. Population replacement in early Neolithic Britain. bioRxiv, p.267443. DOI: $10.1101 / 267443$

Bugajski, J. 2016. Ethnic Politics in Eastern Europe: A Guide to Nationality Policies, Organizations and Parties. London, Routledge.

Dannemann, M. and Kelso, J. 2017. The contribution of Neanderthals to phenotypic variation in modern humans. The American Journal of Human Genetics 101(4), 578-89. DOI: 10.1016/j. ajhg.2017.09.010

Durand, E. Y., Do, C. B., Mountain, J. L. and Macpherson, J.M. 2014. Ancestry composition: a novel, efficient pipeline for ancestry deconvolution. bioRxiv p.010512. DOI:10.1101/010512

Emery, L. S., Magnaye, K. M., Bigham, A. W., Akey, J. M. and Bamshad, M. J. 2015. Estimates of continental ancestry vary widely among individuals with the same mtDNA haplogroup. The American Journal of Human Genetics 96(2), 183-93. DOI: 10.1016/j.ajhg.2014.12.015

Fligstein, N., Polyakova, A. and Sandholtz, W., 2012. European integration, nationalism and European identity. Journal of Common Market Studies 50(s1), 106-122. DOI: 10.1111/j.14685965.2011.02230.x

Fu, Q., Posth, C., Hajdinjak, M., Petr, M., Mallick, S., Fernandes, D, Furtwängler, A., Haak, W., Meyer, M., Mittnik, A., Nickel, B., Peltzer, A., Rohland, N., Slon, V., Talamo, S., Lazaridis, I., Lipson, M., Mathieson, I., Schiffels, S., Skoglund, P., Derevianko, A. P., 
Drozdov, N., Slavinsky, V., Tsybankov, A., Cremonesi, R. G., Mallegni, F., Gély, B., Vacca, E., Morales, M. R. G., Straus, L. G., Neugebauer-Maresch, C., Teschler-Nicola, M., Constantin, S., Moldovan, O. T., Benazzi, S., Peresani, M., Coppola, D., Lari, M., Ricci, S., Ronchitelli, A., Valentin, F., Thevenet, C., Wehrberger, K., Grigorescu, D., Rougier, H., Crevecoeur, I., Flas, D., Semal, P., Mannino, M. A., Cupillard, C., Bocherens, H., Conard, N. J., Harvati, K., Moiseyev, V., Drucker, D. G., Svoboda, J., Richards, M. P., Caramelli, D., Pinhasi, R., Kelso, J., Patterson, N., Krause, J., Pääbo, S. and Reich, D. 2016. The genetic history of Ice Age Europe. Nature 534(7606), 200-205. DOI:10.1038/nature17993

Fujimura, J.H. and Rajagopalan, R. 2011. Different differences: The use of 'genetic ancestry' versus race in biomedical human genetic research. Social Studies of Science 41(1), 5-30. DOI: $10.1177 / 0306312710379170$

Furholt, M., 2018. Massive Migrations? The Impact of Recent aDNA Studies on our View of Third Millennium Europe. European Journal of Archaeology 21(2), 159-191. DOI: 10.1017/eaa.2017.43

Giles, M. and Williams, H. Introduction: mortuary archaeology in contemporary society. In H. Williams and M. Giles (eds), Archaeologists and the Dead: Mortuary Archaeology in Contemporary Society. Oxford, Oxford University Press, 1-18.

Haak, W., Lazaridis, I., Patterson, N., Rohland, N., Mallick, S., Llamas, B., Brandt, G., Nordenfelt, S., Harney, E., Stewardson, K., Fu, Q., Mittnik, A., Bánffy, E., Economou, C., Francken, M., Friederich, S., Pena, R. G., Hallgren, F., Khartanovich, V., Khokhlov, A., Kunst, M., Kuznetsov, P., Meller, H., Mochalov, O., Moiseyev, V., Nicklisch, N., Pichler, S. L., Risch, R., Guerra, M. A. R., Roth, C., Szécsényi-Nagy, A., Wahl, J., Meyer, M., Krause, J., Brown, D., Anthony, D., Cooper, A., Alt, K. W. and Reich, D. 2015. Massive migration from the steppe was a source for IndoEuropean languages in Europe. Nature 522(7555), 207. DOI: $10.1038 /$ nature 14317

Heyd, V. 2017. Kossinna's smile. Antiquity, 91(356), 348-59. DOI: $10.15184 /$ aqy.2017.21 
Hodder, I. 2008. Multivocality and social archaeology. In J. Habu, C. Fawcett and J.M. Matsunaga (eds), Evaluating Multiple Narratives: Beyond Nationalist, Colonialist, Imperialist Archaeologies. New York, Springer, 196-200.

Jobling, M. A., Rasteiro, R. and Wetton, J. H. 2016. In the blood: the myth and reality of genetic markers of identity. Ethnic and Racial Studies 39(2), 142-61 DOI:10.1080/01419870.2016.11 05990

Kershaw, J. and Røyrvik, E. C. 2016. The 'People of the British Isles' project and Viking settlement in England. Antiquity 90(354),1670-80. DOI: 10.15184/aqy.2016.193

Leslie, S., Winney, B., Hellenthal, G., Davison, D., Boumertit, A., Day, T., Hutnik, K., Royrvik, E.C., Cunliffe, B., Lawson, D.J., Falush, D., Freeman, C., Pirinen, M., Myers S., Robinson, M., Donnelly, P. and Bodmer, W. 2015. The fine-scale genetic structure of the British population. Nature 519(7543), 309. DOI:10.1038/nature14230

Llorente, M. G., Jones, E. R., Eriksson, A., Siska, V., Arthur, K. W., Arthur, J. W., Curtis, M. C., Stock, J. T., Coltorti, M., Pieruccini, P., Stretton, S., Brock, F., Higham, T., Park, Y., Hofreiter, M., Bradley, D. G., Bhak, J., Pinhasi, R. and Manica, A. 2015. Ancient Ethiopian genome reveals extensive Eurasian admixture in Eastern Africa. Science, 350(6262), 820-22. DOI: 10.1126/science.aad2879

McClelland, J. and Cerezo-Román, J. 2016. Personhood and reembodiment in osteological practice. In H. Williams and M. Giles (eds), Archaeologists and the Dead: Mortuary Archaeology in Contemporary Society. Oxford, Oxford University Press, 39-67.

Morning, A. 2014. And you thought we had moved beyond all that: biological race returns to the social sciences. Ethnic and Racial Studies 37(10), 1676-85. doi: 10.1080/01419870.2014.931992

Moshenska, G. 2017. Introduction: public archaeology as practice and scholarship where archaeology meets the world. In G. Moshenska (ed.), Key Concepts in Public Archaeology. London, UCL Press, 1-13.

Nash, C. 2004. Genetic kinship. Cultural Studies 18(1), 1-33. DOI: 10.1080/0950238042000181593 
Nash, C. 2005. Geographies of relatedness. Transactions of the Institute of British Geographers 30(4), 449-62.

Nash, C. 2012a. Genetics, race, and relatedness: human mobility and human diversity in the genographic project. Annals of the Association of American Geographers 102(3), 667-84. DOI: 10.1080/00045608.2011.603646

Nash, C., 2012b. Gendered geographies of genetic variation: sex, power and mobility in human population genetics. Gender, Place \& Culture 19(4), 409-28. DOI: 10.1080/0966369X.2011.625085

Nash, C., 2013. Genome geographies: mapping national ancestry and diversity in human population genetics. Transactions of the Institute of British Geographers 38(2), 193-206. DOI: 10.1111/j.1475-5661.2012.00512.x

Nash, C. 2015. Genetic Geographies: The Trouble with Ancestry. Minneapolis, University of Minnesota Press.

Nash, C. 2016. The politics of genealogical incorporation: ethnic difference, genetic relatedness and national belonging. Ethnic and Racial Studies 40(14): 1-19. DOI:10.1080/01419870.201 6.1242763

Nash, C. 2017. Genealogical relatedness: geographies of shared descent and difference. Genealogy 1(2), 7. DOI: 10.3390/ genealogy 1020007

Nordgren, A. and Juengst, E. T. 2009. Can genomics tell me who I am? Essentialistic rhetoric in direct-to-consumer DNA testing. New Genetics and Society 28(2), 157-72. DOI: 10.1080/14636770902901595

Nuthall, K. 1997. There's no place like home says son of Cheddar Man. The Independent 9th March 1997. Retrieved on 22 June 2018 from WWW http://www.independent.co.uk/news/theresno-place-like-home-says-son-of-cheddar-man-1271817.html

Olalde, I., Brace, S., Allentoft, M.E., Armit, I., Kristiansen, K., Booth, T., Rohland, N., Mallick, S., Szécsényi-Nagy, A., Mittnik, A., Altena, E., Altena, E., Lipson, M., Lazaridis, I., Harper, T., Patterson, N., Broomandkhoshbacht, N., Diekmann, Y., 
Faltyskova, Z., Fernandes, D., Ferry, M., Harney, E., Knijff, P., Michel, M., Oppenheimer, J., Stewardson, K., Barclay, A., Alt, K., Liesau, C., Ríos, P., Blasco, C., Miguel, J., García, R., Fernández, A., Bánffy, E., Bernabò-Brea, M., Billoin, D., Bonsall, C., Bonsall, L., Allen, T., Büster, L., Carver, S., Navarro, L., Craig, O., Cook, G., Cunliffe, B., Denaire, A., Dinwiddy, K., Dodwell, N., Ernée, M., Evans, C., Kuchař́k, M., Farré, J., Fowler, C., Gazenbeek, M., Pena, R., Haber-Uriarte, M., Haduch, E., Hey, G., Jowett, N., Knowles, T., Massy, K., Pfrengle, S., Lefranc, P., Lemercier, O., Lefebvre, A., Martínez, C., Olmo, V., Ramírez, A., Maurandi, J., Majó., Mckinley, J., Mcsweeney, K., Mende, B., Mod, A., Kulcsár, G., Kiss, V., Czene, A., Patay, R., Endrődi, A., Köhler, K., Hajdu, T., Szeniczey, T., Dani, J., Bernert, Z., Hoole, M., Cheronet, O., Keating, D., Velemínský, P., Dobeš, M., Candilio, F., Brown, F., Fernández, R., Herrero-Corral, A-M., Tusa, S., Carnieri, E., Lentini, L., Valenti, A., Zanini, A., Waddington, C., Delibes, G., Guerra-Doce, E., Neil, B., Brittain, M., Luke, M., Mortimer, R., Desideri, J., Besse, M., Brücken, G., Furmanek, M., Hałuszko, A., Mackiewicz, M., Rapiński, A., Leach, S., Soriano, I., Lillios, K., Cardoso, J., Parker Pearson, M., Włodarczak, P., Price, T., Prieto, P., Rey, P-J., Risch, R., Guerra, M., Schmitt, A., Serralongue, J., Silva, A., Smrčka, V., Vergnaud, L., Zilhão, J., Caramelli, D., Higham, T., Thomas, M.G., Kennett, D., Fokkens, H., Heyd, V., Sheridan, A., Sjögren, K-G., Stockhammer, P., Krause, J., Pinhasi, R., Haak, W., Barnes, I., Lalueza-Fox, C., and Reich, D. 2018. The Beaker phenomenon and the genomic transformation of northwest Europe. Nature 555, 190-196 DOI:10.1038/nature25738

Oppenheimer, S. 2006. The Origins of the British: A Genetic Detective Story: The Surprising Roots of the English, Irish, Scottish and Welsh. Michigan, Carroll \& Graf.

Panofsky, A. and Donovan, J. 2017. When genetics challenges a racist's identity: genetic ancestry testing among white nationalists. SocArXiv August 17 DOI:10.17605/OSF.IO/7F9BC

Phelan, J. C., Link, B.G., Zelner, S. and Yang, L.H. 2014. Directto-consumer racial admixture tests and beliefs about essential racial differences. Social Psychology Quarterly 77(3), 296-318. DOI: $10.1177 / 0190272514529439$ 
Phillips, A.M., 2016. Only a click away-DTC genetics for ancestry, health, love... and more: A view of the business and regulatory landscape. Applied \& Translational Genomics 8, 16-22. DOI: $10.1016 /$ j.atg.2016.01.001

Prüfer, K., Racimo, F., Patterson, N., Jay, F., Sankararaman, S., Sawyer, S., Heinze, A., Renaud, G., Sudmant, P. H., Filippo, C. D., Li, H., Mallick, S., Dannemann, M., Fu, Q., Kircher, M., Kuhlwilm, M., Lachmann, M., Meyer, M., Ongyerth, M., Siebauer, M., Theunert, C., Tandon, A., Moorjani, P., Pickrell, J., Mullikin, J. C., Vohr, S. H., Green, R. E., Hellmann, I., Johnson, P. L. F., Blanche, H., Cann, H., Kitzman, J. O., Shendure, J., Eichler, E. E., Lein, E. S., Bakken, T. E., Golovanova, L. V., Doronichev, V. B., Shunkov, M. V., Derevianko, A. P., Viola, B., Slatkin, M., Reich, D., Kelso, J., and Pääbo, S. 2014. The complete genome sequence of a Neanderthal from the Altai Mountains. Nature 505(7481), 43. DOI: $10.1038 /$ nature 12886

Ralph, P. and Coop, G. 2013. The geography of recent genetic ancestry across Europe. PLoS Biology 11(5), e1001555. DOI: $10.1371 /$ journal.pbio. 1001555

Reich, D. 2018. Who We Are and How We Got Here: Ancient DNA and the New Science of the Human Past. Oxford, Oxford University Press.

Richardson, L. J. 2014. Understanding archaeological authority in a digital context. Internet Archaeology 38. DOI: 10.11141/ia.38.1

Richardson, L. J. and Almansa-Sánchez, J. 2015. Do you even know what public archaeology is? Trends, theory, practice, ethics. World Archaeology, 47(2), 194-211. DOI: 10.1080/00438243.2015.1017599

Richardson, L. J. and Booth, T. 2017. Response to Brexit, Archaeology and Heritage: Reflections and Agendas. Papers from the Institute of Archaeology 27(1): p.Art 25 DOI: 10.5334/pia-545

Rohde, D. L., Olson, S. and Chang, J. T. 2004. Modelling the recent common ancestry of all living humans. Nature 431(7008), 562. DOI: $10.1038 /$ nature02842 
Royal, C. D., Novembre, J., Fullerton, S. M., Goldstein, D. B., Long, J. C., Bamshad, M. J. and Clark, A. G. 2010. Inferring genetic ancestry: opportunities, challenges, and implications. The American Journal of Human Genetics 86(5), 661-73. DOI: 10.1016/j.ajhg.2010.03.011

Sahakyan, H., Kashani, B. H., Tamang, R., Kushniarevich, A., Francis, A., Costa, M. D., Pathak, A. K., Khachatryan, Z., Sharma, I., Oven, M. V., Parik, J., Hovhannisyan, H., Metspalu, E., Pennarun, E., Karmin, M., Tamm, E., Tambets, K., Bahmanimehr, A., Reisberg, T., Reidla, M., Achilli, A., Olivieri, A., Gandini, F., Perego, U. A., Al-Zahery, N., Houshmand, M., Sanati, M. H., Soares, P., Rai, E., Šarac, J., Šarić, T., Sharma, V., Pereira, L., Fernandes, V., Černý, V., Farjadian, S., Singh, D. P., Azakli, H., Üstek, D., (Trofimova), N. E., Kutuev, I., Litvinov, S., Bermisheva, M., Khusnutdinova, E. K., Rai, N., Singh, M., Singh, V. K., Reddy, A. G., Tolk, H.-V., Cvjetan, S., Lauc, L. B., Rudan, P., Michalodimitrakis, E. N., Anagnou, N. P., Pappa, K. I., Golubenko, M. V., Orekhov, V., Borinskaya, S. A., Kaldma, K., Schauer, M. A., Simionescu, M., Gusar, V., Grechanina, E., Govindaraj, P., Voevoda, M., Damba, L., Sharma, S., Singh, L., Semino, O., Behar, D. M., Yepiskoposyan, L., Richards, M. B., Metspalu, M., Kivisild, T., Thangaraj, K., Endicott, P., Chaubey, G., Torroni, A., and Villems, R. 2017. Origin and spread of human mitochondrial DNA haplogroup U7. Nature Scientific Reports 7. DOI: $10.1038 /$ srep46044

Scodari, C., 2017. When markers meet marketing: ethnicity, race, hybridity, and kinship in genetic genealogy television advertising. Genealogy 1(4), 22. DOI:10.3390/genealogy 1040022

Scully, M., King, T. and Brown, S. D. 2013. Remediating Viking origins: genetic code as archival memory of the remote past. Sociology 47(5), 921-38. DOI: $10.1177 / 0038038513493538$

Scully, M., Brown, S. D. and King, T. 2016. Becoming a Viking: DNA testing, genetic ancestry and placeholder identity. Ethnic and Racial Studies 39(2) 162-180. : 10.1177/0038038513493538

Smith, A.D. 2001. Authenticity, antiquity and archaeology. Nations and Nationalism, 7(4): 441-49. DOI: 10.1111/1469-8219.00026 
Sykes, B. 2006. Blood of the Isles, Exploring the Genetic Roofs of our Tribal History. London, Bantam Press.

TallBear, K. 2013. Native American DNA: Tribal Belonging and the False Promise of Genetic Science. Minneapolis, University of Minnesota Press.

Tutton, R. 2004. 'They want to know where they came from': population genetics, identity, and family genealogy. New Genetics and Society 23(1), 105-20. DOI: 10.1080/1463677042000189606

Wall, J. D., Yang, M. A., Jay, F., Kim, S. K., Durand, E. Y., Stevison, L. S., Gignoux, C., Woerner, A., Hammer, M. F. and Slatkin, M. 2013. Higher levels of Neanderthal ancestry in East Asians than in Europeans. Genetics 194(1), 199-209. DOI: 10.1534/ genetics.112.148213

Wallis, R. J. and Blain, J. 2011. From respect to reburial: negotiating pagan interest in prehistoric human remains in Britain, through the Avebury consultation. Public Archaeology 10(1), 23-45. DO I: $10.1179 / 175355311 X 12991501673186$

Wallis, R. J., 2015. Paganism, archaeology and folklore in twentyfirst-century Britain: a case study of 'The Stonehenge Ancestors'. Journal for the Academic Study of Religion, 28(2). DOI: 10.1558/ jasr.v28i2.26654

Williams, H. and Atkin, A. 2015 Virtually dead: digital public mortuary archaeology, Internet Archaeology 40. DOI: 10.11141/ ia.40.7.4

Zmigrod, L., Rentfrow, P.J. and Robbins, T.W. 2018. Cognitive underpinnings of nationalistic ideology in the context of Brexit. Proceedings of the National Academy of Sciences, p.201708960. DOI: $10.1073 /$ pnas. 1708960115 
